Article

\title{
Precipitation Behavior of Orthorhombic Phase in Ti-22Al-25Nb Alloy during Slow Cooling Aging Treatment and Its Effect on Tensile Properties
}

\author{
Beibei Wei ${ }^{1}$, Bin Tang ${ }^{1,2, *} \mathbb{C}$, Xiaofei Chen ${ }^{1}$, Qin Xu ${ }^{1}$, Shuaijin Zhang ${ }^{3}$, Hongchao Kou ${ }^{1}$ and Jinshan $\mathrm{Li}^{1}$ \\ 1 State Key Laboratory of Solidification Processing, Northwestern Polytechnical University, \\ Xi'an 710072, China; wbb@mail.nwpu.edu.cn (B.W.); chenxf@nwpu.edu.cn (X.C.); \\ 2016260756@mail.nwpu.edu.cn (Q.X.); hchkou@nwpu.edu.cn (H.K.); ljsh@nwpu.edu.cn (J.L.) \\ 2 Shaanxi Key Laboratory of High-Performance Precision Forming Technology and Equipment, \\ Northwestern Polytechnical University, Xi'an 710072, China \\ 3 School of Materials Engineering, Jiangsu University of Technology, Changzhou 213001, China; \\ zhangshuaijin@smail.jsut.edu.cn \\ * Correspondence: toby@nwpu.edu.cn
}

Received: 2 November 2020; Accepted: 13 November 2020; Published: 16 November 2020

check for updates

\begin{abstract}
The precipitation behavior of the orthorhombic $(\mathrm{O})$ phase during the slow cooling aging treatment of Ti-22Al-25 $\mathrm{Nb}$ (at.\%) alloy was investigated by microstructural characterization. Then the effect of $\mathrm{O}$ phase precipitation on the tensile properties was studied by room-temperature tensile tests. The results showed that the precipitation of the $\mathrm{O}$ phase transformed from both grain boundaries and intragranular to only grain boundaries with the temperature increasing. The nucleation mechanism of the $\mathrm{O}$ phase from intergranular is composed of sympathetic nucleation and interface instability nucleation. In addition, the results of tensile tests indicated that the ultimate tensile strength of the alloy decreases as the precipitation of the $\mathrm{O}$ phase increases. Meanwhile, from the tensile results, it is concluded that the optimum heat treatment process is slow cooling after aging at $950{ }^{\circ} \mathrm{C}$ for $1 \mathrm{~h}$.
\end{abstract}

Keywords: Ti-22Al-25Nb alloy; orthorhombic phase; tensile properties; heat treatment

\section{Introduction}

As an important high temperature structural metal, $\mathrm{Ti}_{2} \mathrm{AlNb}$-based alloys have low density, high specific strength, high temperature strength, and excellent creep resistance [1-3]. In comparison with the conventional $\gamma$-TiAl-based alloys which suffer from brittleness and poor fracture toughness [4], $\mathrm{Ti}_{2} \mathrm{AlNb}$-based alloys have better plasticity at room temperature, giving rise to outstanding application potential in aero engines and aerospace [4,5].

Generally, $\mathrm{Ti}_{2} \mathrm{AlNb}$-based alloys are usually composed of $12-25$ at. $\% \mathrm{Al}$ and $12-38$ at. $\% \mathrm{Nb}$. This leads to the fairly complicated phase constituents. Except the hcp (hexagonal close-packed) $\mathrm{Ti}_{3} \mathrm{Al}$ phase and bcc (body-centered cubic) B2 phase [6-8], the orthorhombic $\mathrm{Ti}_{2} \mathrm{AlNb}$ phase (O phase) was observed in the Ti-25Al-12.5 Nb (at.\%) alloy in 1988 for the first time [3]. Subsequent studies revealed that the $\mathrm{O}$ phase has important effects on room temperature plasticity, creep resistance, and high temperature strength of $\mathrm{Ti}_{3} \mathrm{Al}$-based alloys [9]. The plastic deformation of $\mathrm{O}$ phase is mainly carried by $(001)<110>$ slip systems, as well as twinning on (101) planes [1]. Although the alloys with a single $O$ phase were found to have poor room-temperature ductility and toughness, the $O$ phase as a second phase has a positive effect on the mechanical properties. Therefore, the dual-phase $(\mathrm{O}+\mathrm{B} 2) \mathrm{Ti}_{2} \mathrm{AlNb}$ alloys have attracted intensive attention in the past two decades due to their superior mechanical properties [10-12]. Wang et al. reported that after thermomechanical processing followed by solid solution and aging at the $\mathrm{B} 2+\mathrm{O}$ region, a lamellar microstructure was obtained which 
exhibited excellent tensile strength at room and elevated temperatures [13-15]. However, due to the complicated phase transition pathways, the microstructure of $\mathrm{Ti}_{2} \mathrm{AlNb}$-based alloys is quite sensitive to the thermomechanical parameters. As a consequence, the level of thermomechanical processing maturity of $\mathrm{Ti}_{2} \mathrm{AlNb}$-based alloys only reaches $3-5$ to date [16]. Former researches have shown that the behaviors and the mechanism of phase transitions are related to the temperatures of processing, solution, and age-treatments [17]. Thus, it is of significance to reveal the relationship among the heat-treatment temperatures, microstructure, and mechanical properties, especially the effect of precipitation behavior of the $\mathrm{O}$ phase on mechanical properties.

In this paper, the effect of heat treatment parameters on the precipitation behavior of the $\mathrm{O}$ phase during the slow cooling aging treatments of a Ti-22Al-25Nb alloy was studied by the quantitative metallographic statistics based on the microstructure images, and the nucleation mechanism of the $\mathrm{O}$ phase was clarified. In addition, the relationship between the content of the $\mathrm{O}$ phase and its tensile properties was also established.

\section{Experimental}

Table 1 shows the actual composition of Ti-22Al-25Nb (at.\%) alloy. The alloy was prepared by hot rolling and then cut into samples with a dimension of $9 \mathrm{~mm} \times 7 \mathrm{~mm} \times 6 \mathrm{~mm}$ by wire electrical discharge machining. A tubular furnace was used for heat treatment experiments. The involved parameters are shown in Figure 1. The samples were heated to $1080{ }^{\circ} \mathrm{C}$ with a rate of $8{ }^{\circ} \mathrm{C} / \mathrm{min}$, held for $15 \mathrm{~min}$, and then cooled slowly to different temperatures $\left(900^{\circ} \mathrm{C}, 930^{\circ} \mathrm{C}, 950^{\circ} \mathrm{C}\right)$ with a rate of $5{ }^{\circ} \mathrm{C} / \mathrm{min}$. After that, the samples were held for $0.5 \mathrm{~h}, 1 \mathrm{~h}, 1.5 \mathrm{~h}$, and $2 \mathrm{~h}$, respectively, and were then water-quenched to room temperature.

Table 1. The actual composition of Ti-22Al-25Nb alloy used in the present work (wt.\%).

\begin{tabular}{cccccccc}
\hline Rolled Plate & Ti & Al & Nb & C & N & H & O \\
\hline wt. $\%$ & Bal. & 10.11 & 41.25 & 0.0051 & 0.0031 & 0.002 & 0.0471 \\
\hline
\end{tabular}

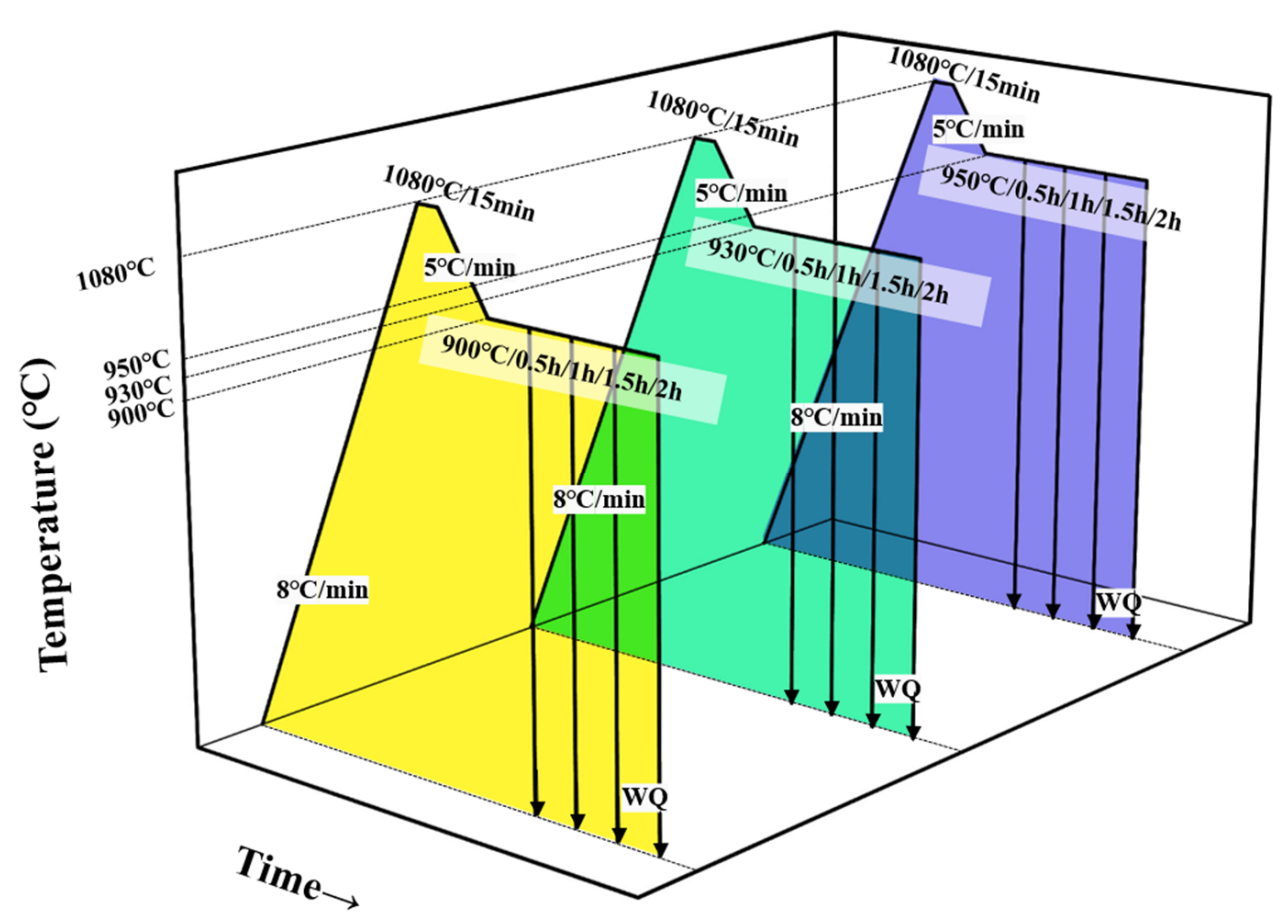

Figure 1. The schematic illustration of the heat treatment process.

The samples were sectioned along the longitudinal direction for microstructure characterization by X-ray diffraction (XRD, PANalytical X'Pert PRO, CuK $\alpha$, (PANalytical B. V, Almelo, Netherlands), 
optical microscopy (OM, OLYMPUS/PMG3, Olympus Corporation, Tokyo, Japan), and scanning electron microscope (SEM, ZEISS SUPRA55, Carl Zeiss AG, Jena, Germany) equipped with electron backscatter diffraction (EBSD) system. After mechanically polished, the samples for OM were etched in the etching solutions of $\mathrm{HF}: \mathrm{HNO}_{3}: \mathrm{H}_{2} \mathrm{O}=1: 3: 8$. The SEM and EBSD samples were electrochemically polished for $18-30 \mathrm{~s}$ at $20-25 \mathrm{~V}$ and about $18{ }^{\circ} \mathrm{C}$ in the solution of $6 \mathrm{vol} \%$ perchloric acid $+34 \mathrm{vol} \%$ butanol $+60 \mathrm{vol} \%$ methanol. The quantitative metallographic analysis was performed using the Image-Pro Plus 5.0 (IPP) software (Media Cybernetics, MD, USA). The grain size was evaluated by using the line-intercept method according to GB/T 6394-2017. The EBSD analysis was conducted with a step of $0.2 \mu \mathrm{m}$ and analyzed by the HKL-Channel 5 software (HKL, Oxford, UK).

For tensile tests, the samples with a dimension of $65 \mathrm{~mm} \times 10 \mathrm{~mm} \times 8 \mathrm{~mm}$ were machined from the as-rolled sheet and then machined into a gauge dimension of $\Phi 5 \mathrm{~mm} \times 30 \mathrm{~mm}$ after various heat treatments, as shown in Figure 2. The tensile tests were carried out on an Instron-3362 machine (Instron, Boston, MA, USA) with a constant speed of rate of $0.001 \mathrm{~mm} / \mathrm{s}$. At least three sets of tensile tests were conducted at each condition.

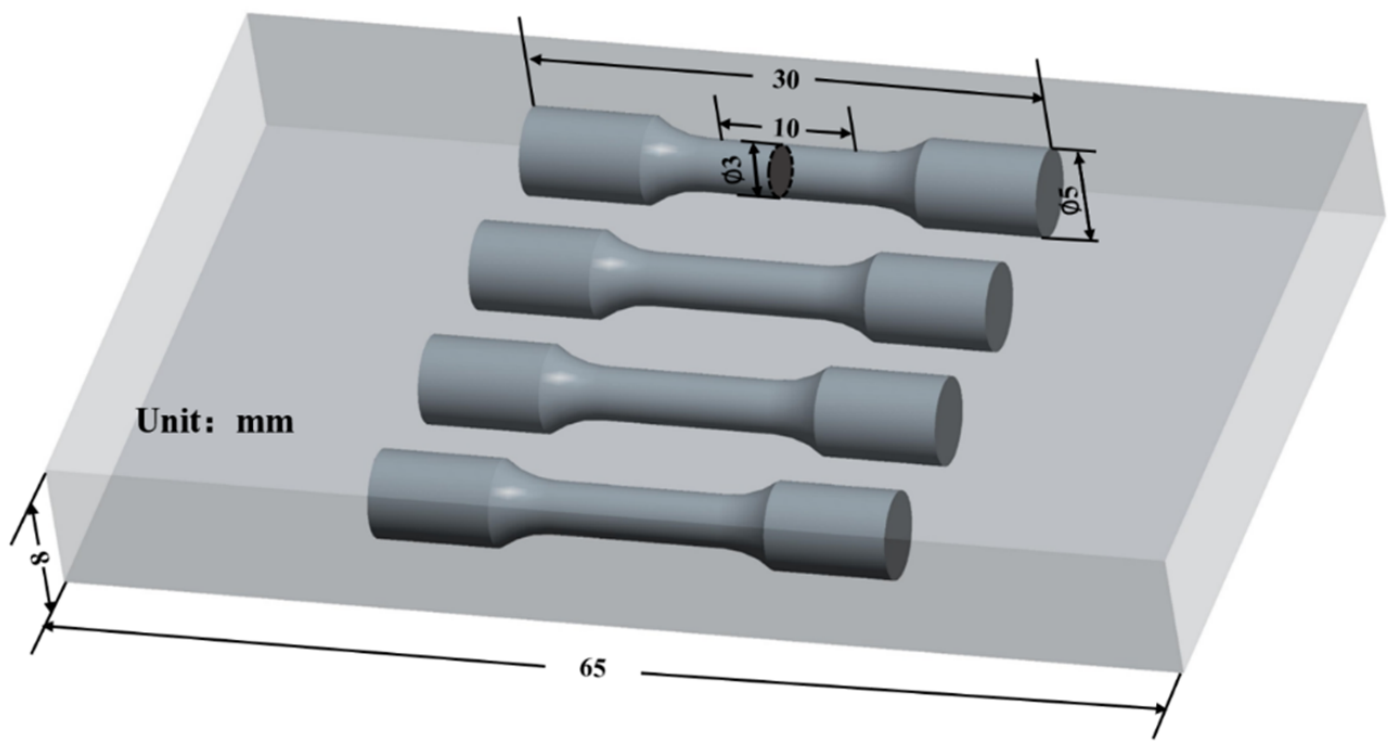

Figure 2. Machining drawing of the tensile specimens.

\section{Results and Discussion}

\subsection{Initial Microstructure}

Figure 3a shows the XRD patterns of the as-rolled sheet, it can be concluded that the initial microstructure mainly consists of the $\mathrm{O}$ phase and B2 phase. In Figure 3b, it can be seen that the initial grain size of the B2 phase is relatively large with an average size of about $160 \mu \mathrm{m}$. According to the BSE (back-scattered electron) image in Figure 3c, numerous $\mathrm{O}$ phases with acicular shape are precipitated in the matrix of the B2 phase, while the sizes are far from identical.

From Figure $3 \mathrm{~d}-\mathrm{f}$, it can be seen that the microstructure after solution treatment sample consists of a single B2 phase with grain sizes ranging from 60 to $350 \mu \mathrm{m}$. Obviously, the mean grain size is larger than that in the initial state, indicating inevitable grain growth when the solution is treated in the single-phase region. 

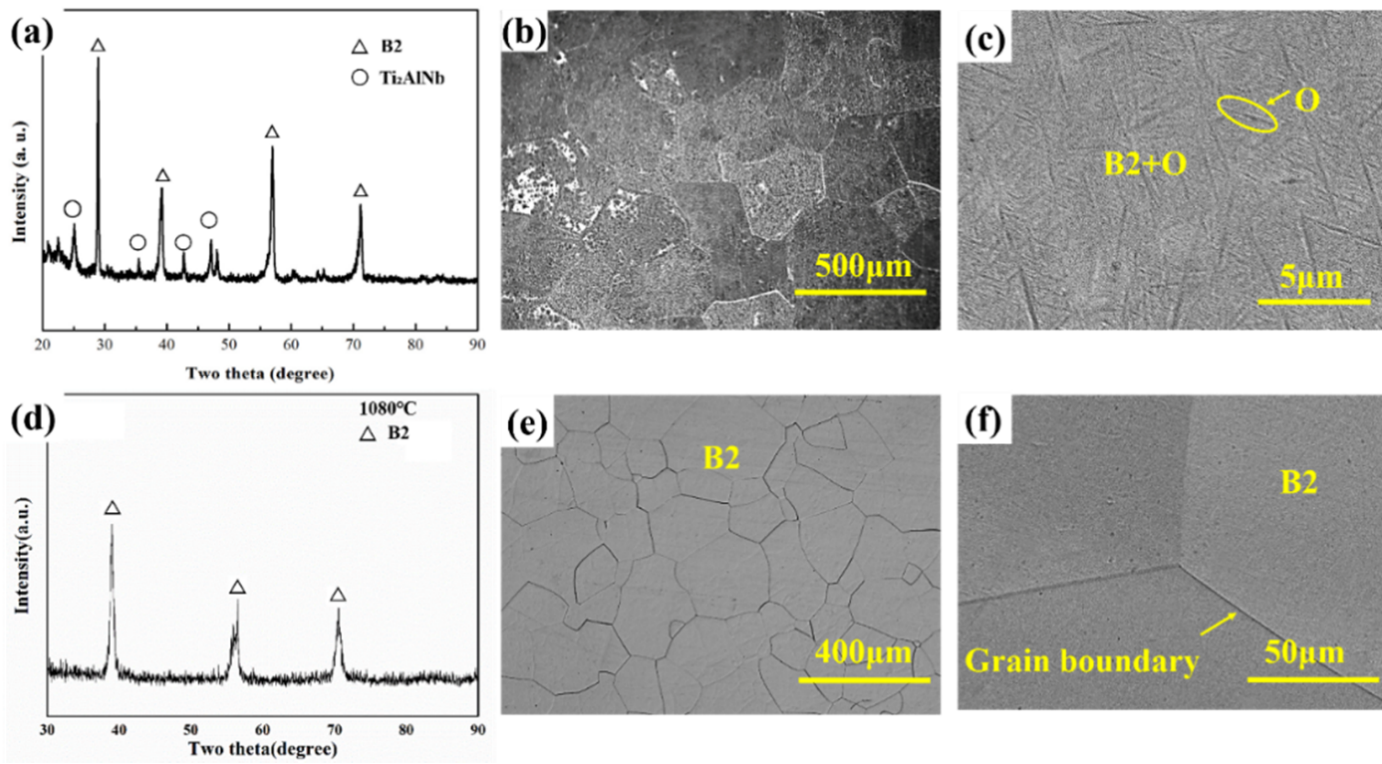

Figure 3. Initial microstructure $(\mathbf{a}-\mathbf{c})$ and the one after solution treatment at $1080{ }^{\circ} \mathrm{C}$ for $15 \mathrm{~min}$ (d-f) for the rolled Ti-22Al-25Nb alloy. (a,d) XRD patterns, (b,e) optical microscopy (OM) images, $(\mathbf{c}, \mathbf{f})$ back-scattered electron (BSE) images.

\subsection{Precipitation Behavior of the $O$ Phase}

To understand the precipitation behavior of the $\mathrm{O}$ phase, the heat treatment of Ti-22Al- $25 \mathrm{Nb}$ alloy in Figure 1, named as the slow cooling aging, was carried out. Obviously, the heat-treated microstructure at $900-950{ }^{\circ} \mathrm{C} / 0.5 \mathrm{~h}$ is mainly composed of the B2 phase and O phase as shown in Figure $4 \mathrm{a}-\mathrm{c}$. The precipitation of the $\mathrm{O}$ phase transformed from both grain boundaries and intragranular to only grain boundaries with the temperature increase. When the aging temperature is below $950{ }^{\circ} \mathrm{C}$, the acicular $\mathrm{O}$ phase is distributed in the intragranular and grain boundaries. According to the diagram of Ti-22Al- $x \mathrm{Nb}$ phase [18], the approximate phase regions of the alloy were $\mathrm{B} 2+\mathrm{O}<955{ }^{\circ} \mathrm{C}<\mathrm{B} 2+\mathrm{O}+\alpha_{2}<1010{ }^{\circ} \mathrm{C}<\mathrm{B} 2+\alpha_{2}<1065^{\circ} \mathrm{C}<\mathrm{B} 2$, which indicates that $900{ }^{\circ} \mathrm{C}$ and $930^{\circ} \mathrm{C}$ is far from the transition point of the $\mathrm{B} 2+\mathrm{O}$ two-phase region and the $\mathrm{B} 2+\mathrm{O}+\alpha_{2}$ three-phase region $\left(950-960^{\circ} \mathrm{C}\right)$. The higher degree of subcooling can achieve the higher driving force. Accordingly, the $\mathrm{O}$ phase tends to nucleate simultaneously in the grain boundary and intragranular. The average size of the $\mathrm{O}$ phase at $930^{\circ} \mathrm{C}(75 \mu \mathrm{m})$ is larger than that at $900{ }^{\circ} \mathrm{C}(45 \mu \mathrm{m})$. With the increase of temperature, the $\mathrm{O}$ phase nucleates preferentially at grain boundary. The driving force for coarsening derived from the interfacial energy $[19,20]$. However, the globular O phase only exists at grain boundaries when the aging temperature reaches $950{ }^{\circ} \mathrm{C}$. The driving force of spheroidization is provided by the reduction in interface energy [21]. The volume fraction of precipitated O phase is counted by IPP. The statistical results are shown in Figure $4 \mathrm{~d}$. It can be seen that the volume fraction of the $\mathrm{O}$ phase reached more than $50 \%$ at $900{ }^{\circ} \mathrm{C}$, while it is less than $5 \%$ at $950{ }^{\circ} \mathrm{C}$, indicating that the precipitation of the $\mathrm{O}$ phase decreased significantly as the temperature increased.

Figure 5 shows the heat-treated microstructure under various conditions. Distinctly, as the aging time increases, the precipitation of the $\mathrm{O}$ phase is promoted. The nucleation and growth of the $\mathrm{O}$ phase can occur both in the intragranular and grain boundaries. The quantitation metallographic statistic was performed based on the images. The results in Figure 6 demonstrated that the volume fraction of the acicular $\mathrm{O}$ phase increases with the decrease of aging temperature and the increase of time. In addition, the volume fraction of the $\mathrm{O}$ phase increases obviously at $900{ }^{\circ} \mathrm{C}$ during the initial $0.5 \mathrm{~h}$. Then the growth rate decreases quickly during the subsequent aging process. Similarly, the volume fraction of the $\mathrm{O}$ phase increases steadily at $930^{\circ} \mathrm{C}$ with the increasing time. However, the growth rate is constant and is lower than that at $900{ }^{\circ} \mathrm{C} / 0.5 \mathrm{~h}$. When the aging temperature increased to close to the transition point of the $\mathrm{B} 2+\mathrm{O}$ two-phase region and the $\mathrm{B} 2+\mathrm{O}+\alpha_{2}$ three-phase region, defined as $\mathrm{T}_{2 \rightarrow 3}$, such as 
$950^{\circ} \mathrm{C}$, there is nearly no nucleation of $\mathrm{O}$ phase occurring at the initial aging stage until the aging time extended to $1.5 \mathrm{~h}$. The volume fraction of the $\mathrm{O}$ phase increases heavily during the subsequent process. Furthermore, the precipitation rate of the $\mathrm{O}$ phase reached the highest point at $900{ }^{\circ} \mathrm{C} / 0.5 \mathrm{~h}$.
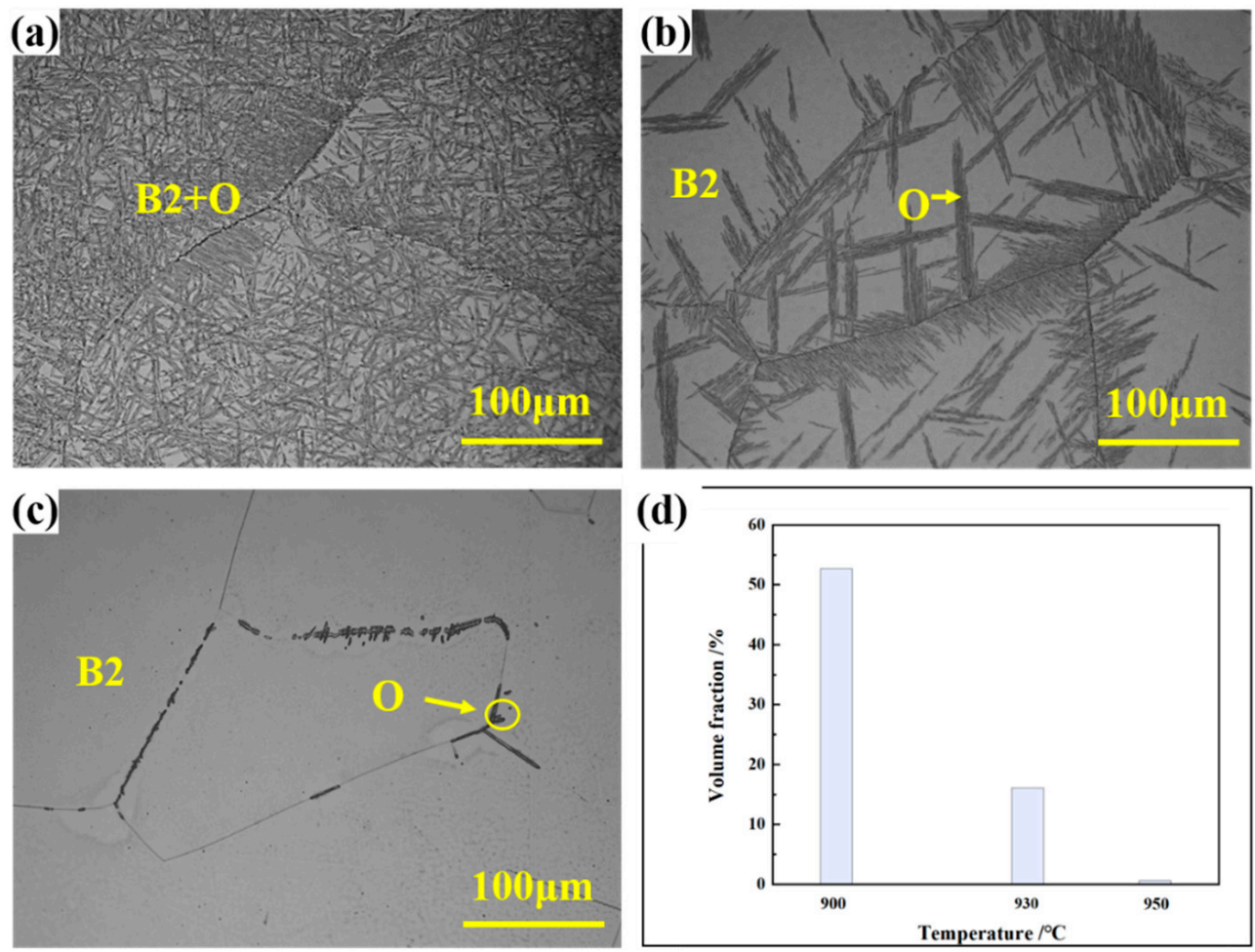

Figure 4. Microstructure of Ti-22Al-25Nb alloy held for $30 \mathrm{~min}$ at different temperatures. (a) $900{ }^{\circ} \mathrm{C}$, (b) $930{ }^{\circ} \mathrm{C},(\mathbf{c}) 950^{\circ} \mathrm{C}$, (d) statistical results for the volume fraction of the orthorhombic (O) phase.

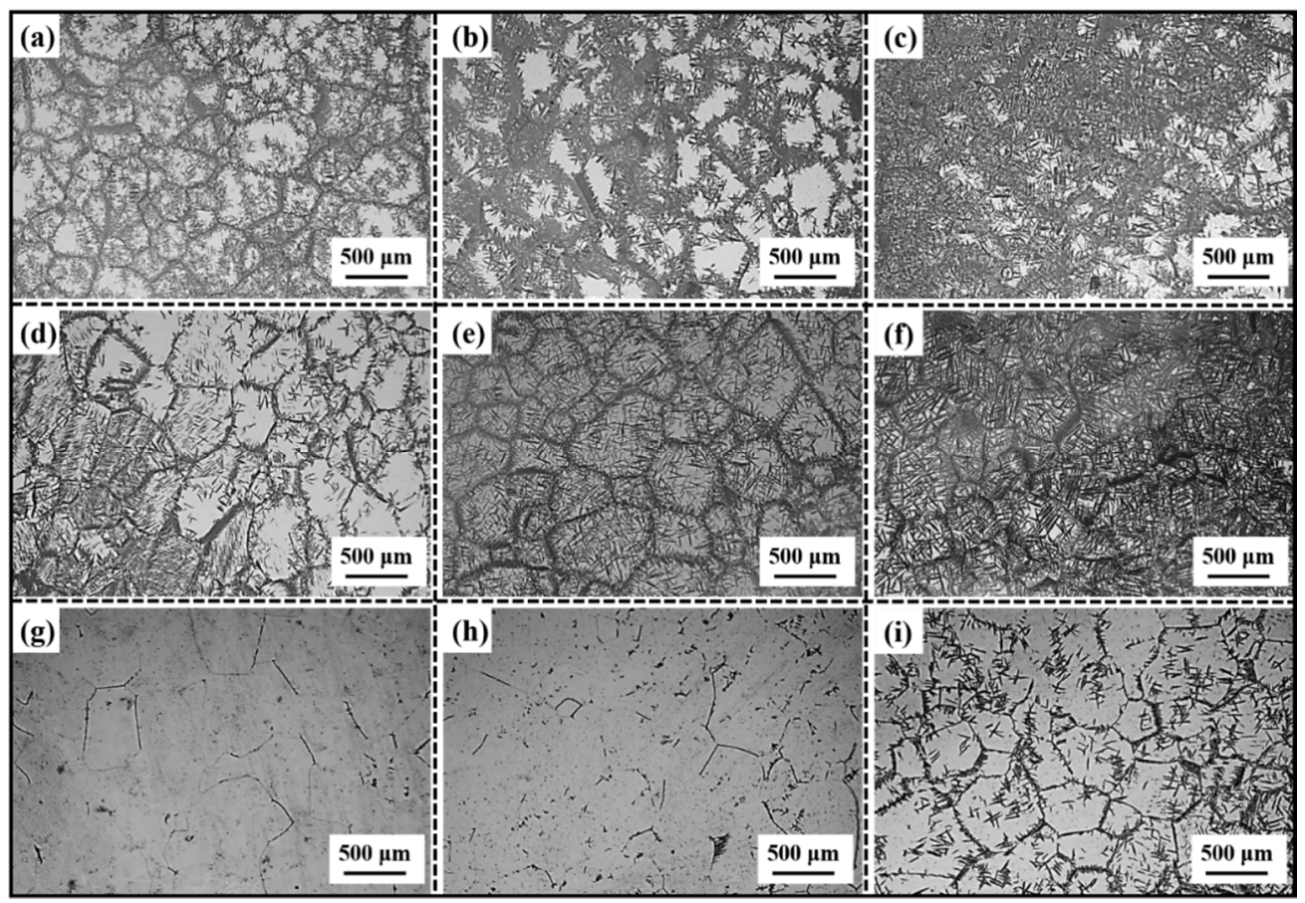

Figure 5. The $\mathrm{OM}$ images of the heat-treated Ti-22Al-25Nb alloy at (a) $900{ }^{\circ} \mathrm{C} / 1 \mathrm{~h},(\mathbf{b}) 900{ }^{\circ} \mathrm{C} / 1.5 \mathrm{~h}$, (c) $900{ }^{\circ} \mathrm{C} / 2 \mathrm{~h}$, (d) $930{ }^{\circ} \mathrm{C} / 1 \mathrm{~h},\left(\right.$ e) $930{ }^{\circ} \mathrm{C} / 1.5 \mathrm{~h}$, (f) $930{ }^{\circ} \mathrm{C} / 2 \mathrm{~h},\left(\right.$ g) $950{ }^{\circ} \mathrm{C} / 1 \mathrm{~h}$, (h) $950{ }^{\circ} \mathrm{C} / 1.5 \mathrm{~h}$, and (i) $950^{\circ} \mathrm{C} / 2 \mathrm{~h}$. 


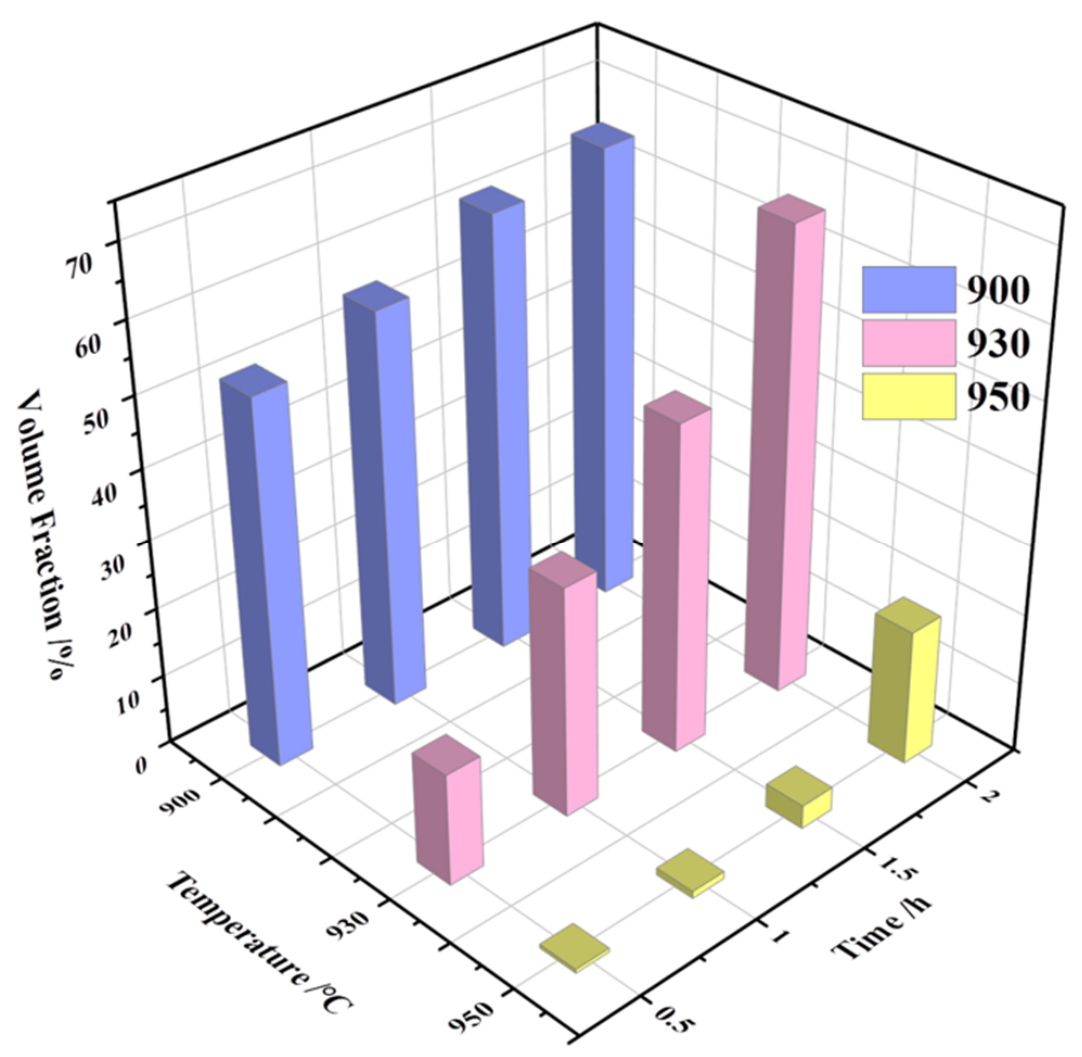

Figure 6. The volume fraction of the acicular $\mathrm{O}$ phase varies with temperature and time.

Due to the limitation of OM magnification, the heat-treated samples at $900-950{ }^{\circ} \mathrm{C} / 1-2 \mathrm{~h}$ were selected for SEM observations. The corresponding microstructure is shown in Figure 7 . It is found that the acicular $\mathrm{O}$ phase which precipitates at $900{ }^{\circ} \mathrm{C} / 1 \mathrm{~h}$ can grow up into the lath cluster with thicknesses of $10-50 \mu \mathrm{m}$ when holding at $900^{\circ} \mathrm{C}$ for $2 \mathrm{~h}$. At $930{ }^{\circ} \mathrm{C} / 1 \mathrm{~h}$, the $\mathrm{O}$ phase precipitates along the grain boundaries at a certain angle and then continues to nucleate and grow up nearly perpendicular to the $\mathrm{O}$ phase which has already precipitated. When the aging time increases to $2 \mathrm{~h}$, it can be seen that the $\mathrm{O}$ phase precipitates discontinuously. The $\mathrm{O}$ phase is broken and refined due to the collision of $\mathrm{O}$ phase laths. Moreover, almost all $\mathrm{O}$ phases precipitate along the grain boundaries at $950{ }^{\circ} \mathrm{C}$.
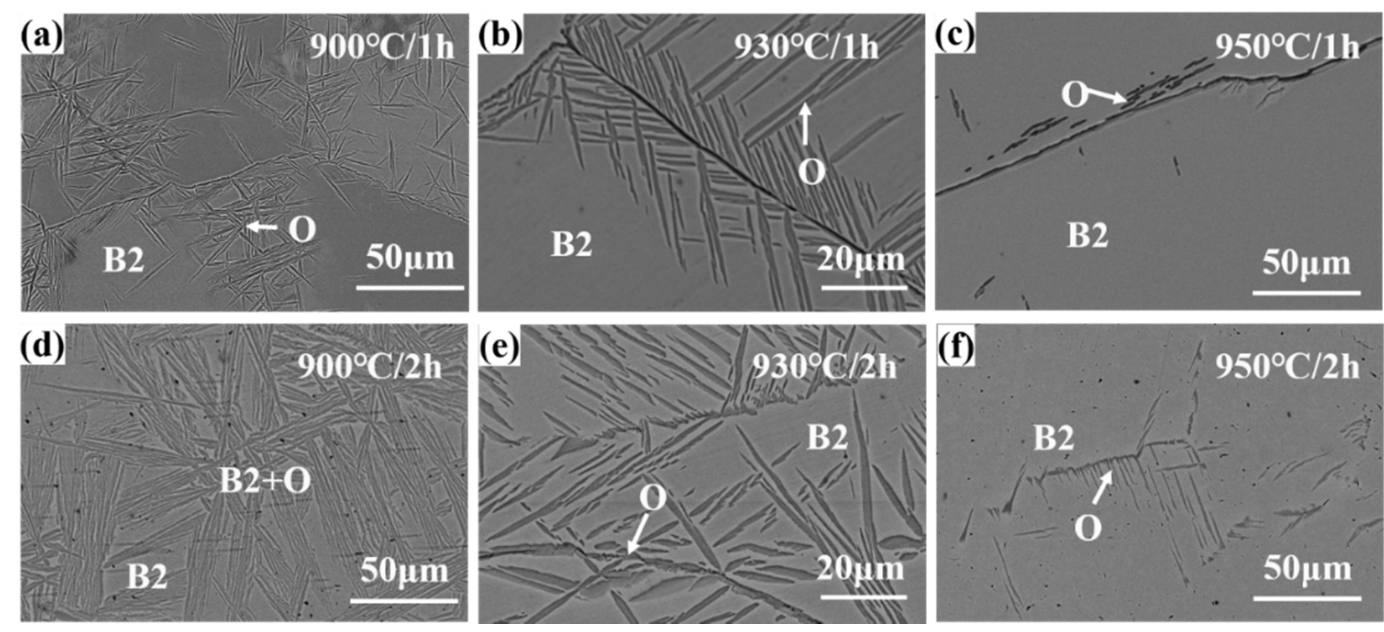

Figure 7. The BSE images of the heat-treated Ti-22Al-25Nb alloy at (a) $900{ }^{\circ} \mathrm{C} / 1 \mathrm{~h}$, (b) $930{ }^{\circ} \mathrm{C} / 1 \mathrm{~h}$, (c) $950{ }^{\circ} \mathrm{C} / 1 \mathrm{~h},(\mathbf{d}) 900^{\circ} \mathrm{C} / 2 \mathrm{~h},(\mathbf{e}) 930^{\circ} \mathrm{C} / 2 \mathrm{~h},\left(\right.$ f) $950{ }^{\circ} \mathrm{C} / 2 \mathrm{~h}$. 


\subsection{Nucleation Mechanism of the O Phase}

In this work, two kinds of nucleation mechanisms of the $\mathrm{O}$ phase from grain boundaries are observed-sympathetic nucleation and interface instability nucleation [22]. The continuous $\alpha$ layers along the $\beta / \beta$ grain boundary denoted $\alpha_{\mathrm{GB}}$, and Widmanstätten plates colonies denoted $\alpha_{\mathrm{WGB}}[23,24]$. Sympathetic nucleation will lead to different orientations between $\alpha_{\mathrm{WGB}}$ and $\alpha_{\mathrm{GB}}$, while $\alpha_{\mathrm{WGB}}$ grows up from $\alpha_{\mathrm{GB}}$ grain with the same orientation due to interface instability. The orientation relationship (OR) between the $\mathrm{O}$ phase and the $\mathrm{B} 2$ phase satisfies the well-known Burgers OR, $\{001\}_{\mathrm{O}} / /\{110\}_{\mathrm{B} 2}$, $<110>_{\mathrm{O}} / /<111>_{\mathrm{B} 2}[8,25]$. Under ideal conditions, there are 12 variants of the $\mathrm{O}$ phase with different orientations that can precipitate in the B2 matrix [26]. However, these variants will not precipitate with the same probability due to various reasons, and the variants selection of the $O$ phase occurs during the process of nucleation and growth $[27,28]$. The EBSD measurements of the orientation parameters were performed on a triangle grain boundary of B2 phase obtained at $900{ }^{\circ} \mathrm{C} / 0.5 \mathrm{~h}$. Figure $8 \mathrm{a}, \mathrm{b}$ shows the inverse pole figures (IPF) of the $\mathrm{O}$ phase and B2 matrix respectively, and Figure $8 \mathrm{c}$ shows the pole figures $(\mathrm{PF})$ of the sites marked in Figure 8a,b. The $\mathrm{O}$ phase precipitated from the grain boundaries is named $\mathrm{O}_{\mathrm{GB}}$. $\mathrm{O}_{\mathrm{G} 1}, \mathrm{O}_{\mathrm{G} 2}$, and $\mathrm{O}_{\mathrm{G} 3}$ refer to the $\mathrm{O}_{\mathrm{GB}}$. Moreover, it was found that some $\mathrm{O}$ phase variants nucleate in the vicinity of $\mathrm{O}_{\mathrm{GB}}$ and then grow into the $\beta$ grains. $\mathrm{O} 1$ is a variant nucleated at $\mathrm{O}_{\mathrm{G} 1}$, and $\mathrm{O} 2, \mathrm{O} 3$ are the variants nucleated at $\mathrm{O}_{\mathrm{G} 2}$. Obviously, the orientation of $\mathrm{O}_{\mathrm{G} 1}$ is consistent with that of $\mathrm{O} 1$ as shown in Figure 8c. This is a typical interface instability nucleation behavior. Furthermore, the ORs of $\mathrm{O} 1, \mathrm{O}_{\mathrm{G} 1}$, and b1 satisfy the Burgers ORs. However, the O phase variants precipitated in b2, such as $\mathrm{O} 2$ and $\mathrm{O} 3$, have different orientations with $\mathrm{O}_{\mathrm{G} 2}$. It is also strong evidence that there are two kinds of nucleation mechanisms of the $\mathrm{O}$ phase from grain boundaries-sympathetic nucleation and interface instability nucleation. Through the analysis, six kinds of variants precipitated in b2 have a certain orientation relationship with b2 grains, (001)O//(110)B2,[111]B2//[110]O. The $\mathrm{O}_{\mathrm{G} 3}$ and b3 grains also satisfy the above orientation relationship.

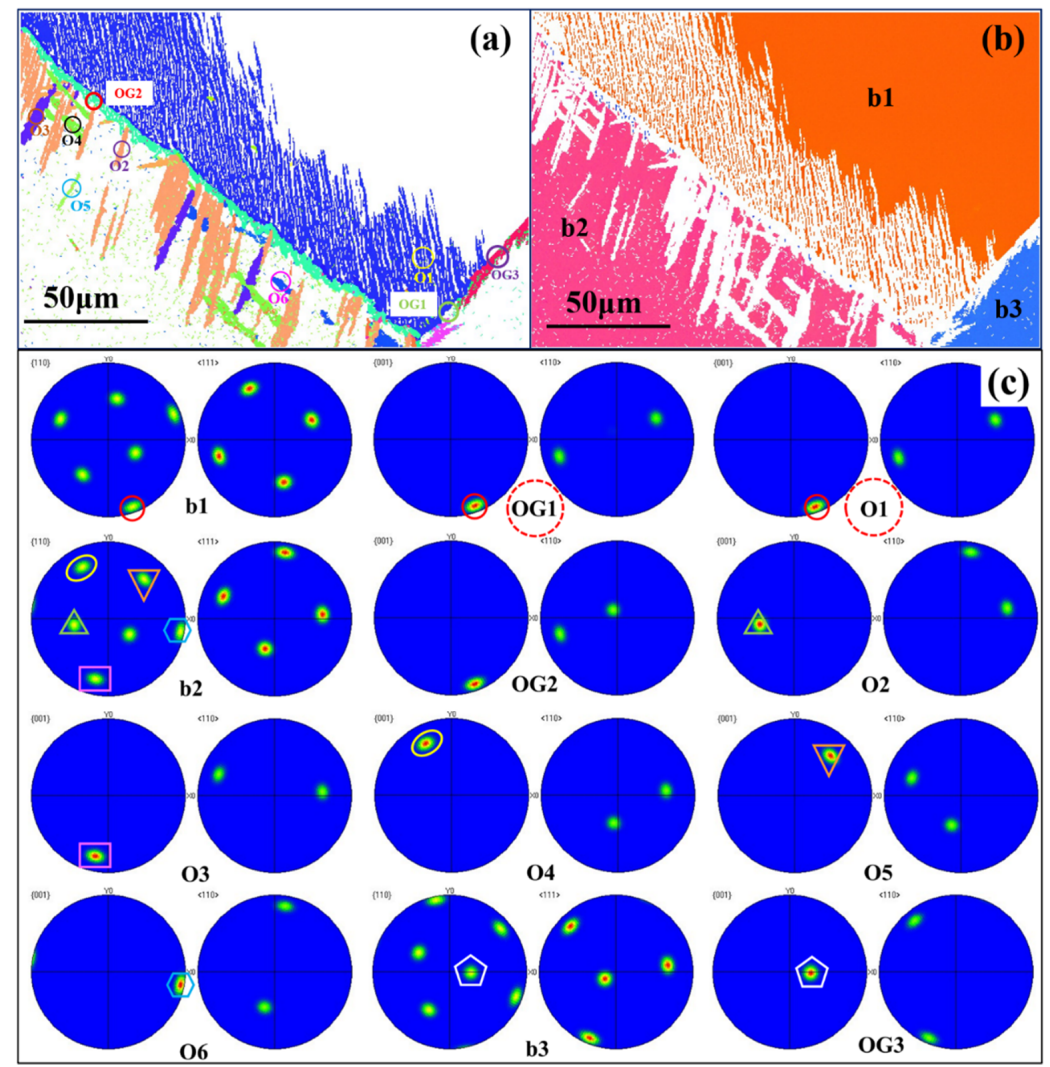

Figure 8. The inverse pole figures (IPF) maps (a) of $O$ phase and (b) of B2 phase. (c) The $\{110\}$, $<111>$ pole figures of $\mathrm{B} 2$ phase and the $\{001\},<110>$ pole figures of $\mathrm{O}$ variants. 


\subsection{Tensile Properties}

Based on the above analysis, the volume fraction of the $\mathrm{O}$ phase increases with the decrease of aging temperature and the increase of time, as shown in Figure 6. To figure out the effect of the $\mathrm{O}$ phase on mechanical properties of Ti-22Al-25Nb alloy, room-temperature tensile tests of the heat-treated samples were carried out. Figure $9 \mathrm{a}-\mathrm{c}$ shows the tensile curve of the samples at different conditions. It can be seen that the elongation of the alloy at $900{ }^{\circ} \mathrm{C}$ is lower than that of at $930{ }^{\circ} \mathrm{C}$ and $950{ }^{\circ} \mathrm{C}$ after aging for $0.5 \mathrm{~h}$. As it was known, the $\mathrm{O}$ phase suffers from a lower number of available slip systems compared with the B2 structure [29]. The high-volume fraction of the O phase was considered to be the probable reason for this exhibition at $900{ }^{\circ} \mathrm{C}$ [30]. It can be seen that the elongation tends to increase with time at $900^{\circ} \mathrm{C}$. It can be interpreted that most of the $\mathrm{O}$ phase preferentially precipitates at the grain boundaries and then grows into the B2 matrix. During the subsequent aging process, the preferentially precipitated $\mathrm{O}$ phase grows up and gathers into a lath cluster. This $\mathrm{O}$ phase cluster is larger in size than the individual $\mathrm{O}$ phase, and the plasticity of the large-size $\mathrm{O}$ phase is superior to that of the small-size $\mathrm{O}$ phase $[13,31]$. The elongation of the alloy decreases with the prolongation of aging time due to the gradual precipitation of $\mathrm{O}$ phase at $930{ }^{\circ} \mathrm{C}$ and $950{ }^{\circ} \mathrm{C}$. Compared with this, the initial precipitation amount of the $\mathrm{O}$ phase at $900{ }^{\circ} \mathrm{C}$ has reached $50 \%$, and then the growth of the $\mathrm{O}$ phase is the main process. At $930{ }^{\circ} \mathrm{C}$ and $950{ }^{\circ} \mathrm{C}$, the precipitation process of the $\mathrm{O}$ phase is the dominant, the size of the precipitated $\mathrm{O}$ phase is relatively large, but its volume fraction is lower, which cannot grow into clusters. Thus, the elongation of the alloy decreases with the increase of O phase precipitation. Figure $9 \mathrm{~d}$ shows the relationship between the ultimate strength (UTS) and the temperature of the alloy. It can be seen that the UTS of the samples heat-treated at $900{ }^{\circ} \mathrm{C}$ is the lowest. On the contrary, the volume fraction of the $\mathrm{O}$ phase at $900{ }^{\circ} \mathrm{C}$ is the highest in the same aging time. With the increase in the aging temperature, the volume fraction of the $O$ phase decreased. At the early stage of aging, the UTS of the alloy at different temperatures varies slightly, such as $0.5 \mathrm{~h}$. With the extension of aging time, the precipitation of the $\mathrm{O}$ phase increased. In the subsequent aging process, the decrease rate of UTS at $900{ }^{\circ} \mathrm{C}$ is greater than that of at $930{ }^{\circ} \mathrm{C}$. Boehlert [30] found that when the volume fraction of the $\mathrm{O}$ phase reaches $28 \%$, the UTS of the alloy with the $\mathrm{B} 2+\mathrm{O}$ microstructure is higher than that of the full B2 microstructure for the Ti-12Al-38Nb alloy. The precipitation of the O phase can strengthen the matrix, but the corresponding plasticity will lose a little. When the volume fraction of the $\mathrm{O}$ phase reaches $79 \%$, both strength and plasticity will reduce significantly. In addition, the thickness of lamellar $\mathrm{O}$ affects the tensile properties, as has been known that the coarse lamellar $\mathrm{O}$ exhibits poor strengthening effect compared with the fine lamellar $\mathrm{O}$ [32]. It can be seen from Figure 7a, the thickness of lamellar O gradually increased with the increase of time at $900{ }^{\circ} \mathrm{C}$. Therefore, although the volume fraction of the $\mathrm{O}$ phase increased with the increase of time, the UTS of the alloy decreased. When aging at $950{ }^{\circ} \mathrm{C}$, the content of the $\mathrm{O}$ phase is very small at the initial aging stage. As mentioned previously, a small amount of the $\mathrm{O}$ phase can strengthen the matrix, but when the volume fraction of the $\mathrm{O}$ phase increases to a certain extent, the strength of the alloy will be sacrificed. This is the reason why the strength experiences the first increase then decrease process at $950{ }^{\circ} \mathrm{C}$. The strength of the alloy reaches the highest at $950{ }^{\circ} \mathrm{C} / 1 \mathrm{~h}$. 

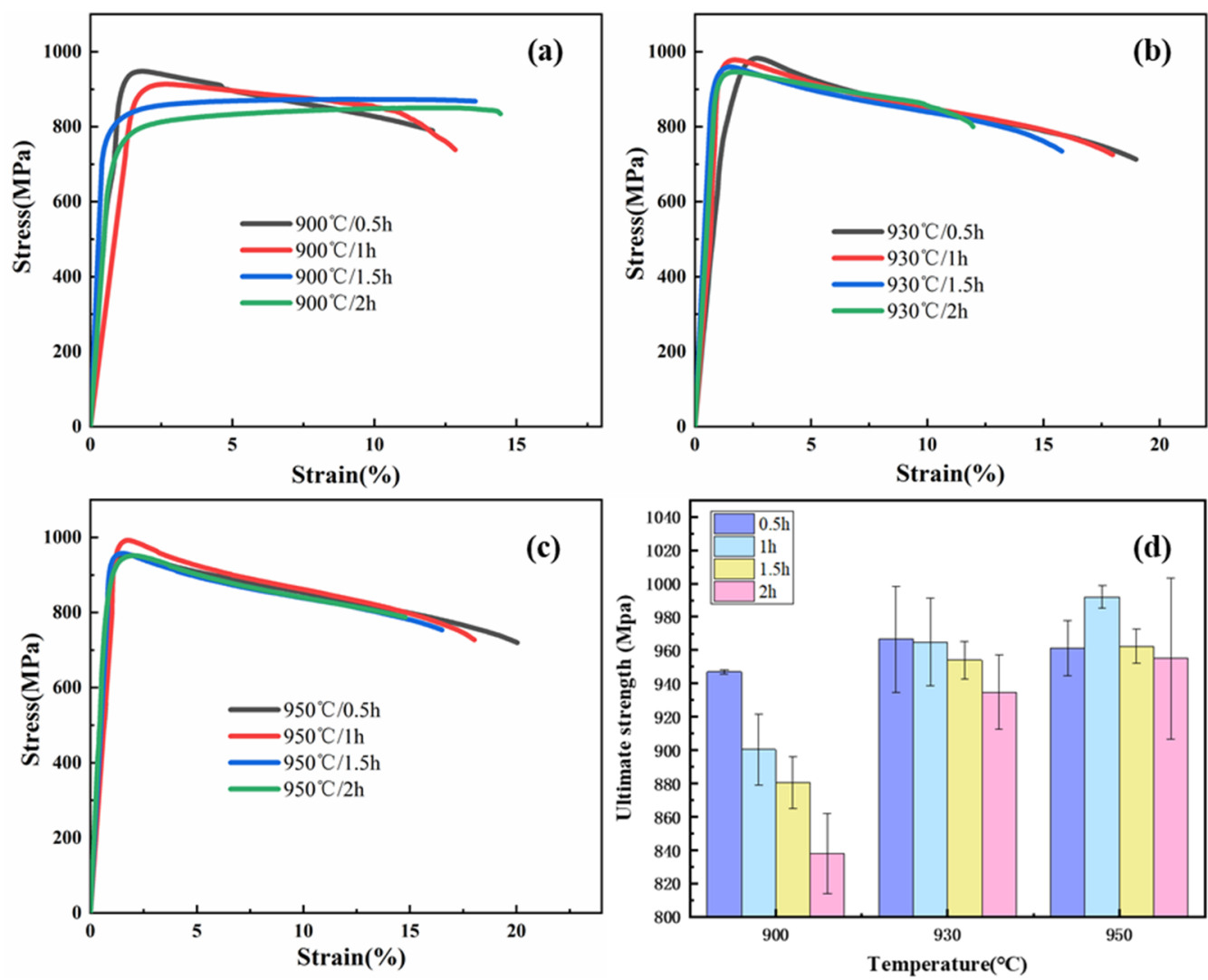

Figure 9. The effect of $\mathrm{B} 2$ slow cooling to aging treatment to ambient tensile curve for Ti-22Al- $25 \mathrm{Nb}$ alloy: (a) $900{ }^{\circ} \mathrm{C} / 0-2 \mathrm{~h},(\mathbf{b}) 930^{\circ} \mathrm{C} / 0-2 \mathrm{~h},(\mathbf{c}) 950{ }^{\circ} \mathrm{C} / 0-2 \mathrm{~h}$, (d) the ultimate strength (UTS) of the alloy at different temperatures.

\section{Conclusions}

(1) The acicular $\mathrm{O}$ phase precipitated from both the grain boundaries and the intragranular when aging at $900{ }^{\circ} \mathrm{C}$. Increasing the temperature to $930^{\circ} \mathrm{C}$, the acicular $\mathrm{O}$ phase tends to precipitate from the grain boundaries. In addition, the average size of the $\mathrm{O}$ phase at $930^{\circ} \mathrm{C}$ is larger than that at $900^{\circ} \mathrm{C}$. When aging at $950^{\circ} \mathrm{C}$, only a few globular $\mathrm{O}$ phases could be found at grain boundaries.

(2) Under the condition of B2 slow cooling aging, there are two modes of nucleation mechanism of O phase from grain boundaries-sympathetic nucleation and interface instability nucleation.

(3) With the increase of aging temperature, the volume fraction of the $\mathrm{O}$ phase decreased and the strength of the alloy increased. The strength of the alloy decreases with the increase of aging time when aging at $900{ }^{\circ} \mathrm{C}$ and $930^{\circ} \mathrm{C}$. When aging at $950^{\circ} \mathrm{C}$, strength experiences a first increase then decrease process. The reasonable match between strength could be obtained at $950^{\circ} \mathrm{C} / 1 \mathrm{~h}$.

Author Contributions: B.W. interpreted data and wrote the paper. B.T. performed experiments and analysed the data. X.C. analysed the data. Q.X. processed the figures. S.Z. revised the language of the paper. H.K. and J.L. provided funds for the study. All authors discussed the results and commented on the manuscript. All authors have read and agreed to the published version of the manuscript.

Funding: This work was financially supported by the Aeronautical Science Foundation of China (No. 201936053001), the National Natural Science Foundation of China (No.51771150), the Natural Science Foundation of Shaanxi Province (2018JM5174), the Research Fund of the State Key Laboratory of Solidification Processing (NPU), China (Grant No. 2019-TS-07), and the Postgraduate Research \& Practice Innovation Program of Jiangsu Province (SJCX19_0732).

Acknowledgments: We would like to thank the Analytical \& Testing Center of Northwestern Polytechnical University for SEM testing.

Conflicts of Interest: The authors declare no conflict of interest. 


\section{References}

1. Huang, S.H.; Shao, B.; Xu, W.C.; Shan, D.B.; Guo, B.; Zong, Y.Q. Deformation Behavior and Dynamic Recrystallization of Ti-22Al-25Nb Alloy at 750-990 ${ }^{\circ}$ C. Adv. Eng. Mater. 2019, 22, 1901231. [CrossRef]

2. Gogia, A.K.; Nandy, T.K.; Banerjee, D.; Carisey, T.; Strudel, J.L. Microstructure and mechanical properties of orthorhombic alloys in the Ti-Al-Nb system. Intermetallics 1998, 6, 741-748. [CrossRef]

3. Banerjee, D.; Gogia, A.K.; Nandy, T.K.; Joshi, V.A. A new ordered orthorhombic phase in a Ti3Al-Nb alloy. Acta Metall. 1988, 36, 871-882. [CrossRef]

4. Clemens, H.; Mayer, S. Design, Processing, Microstructure, Properties, and Applications of Advanced Intermetallic TiAl Alloys. Adv. Eng. Mater. 2013, 15, 191-215. [CrossRef]

5. Zhang, Y.L.; Feng, A.H.; Qu, S.J.; Shen, J.; Chen, D.L. Microstructure and low cycle fatigue of a Ti2AlNb-based lightweight alloy. J. Mater. Sci. Technol. 2020, 44, 140-147. [CrossRef]

6. Pathak, A.; Singh, A.K. A first principles study of Ti2AlNb intermetallic. Solid State Commun. 2015, 204, 9-15. [CrossRef]

7. Boehlert, C.J.; Majumdar, B.S.; Seetharaman, V.; Miracle, D.B. Part I. The microstructural evolution in Ti-Al-Nb O+Bcc orthorhombic alloys. Metall. Mater. Trans. A 1999, 30, 2305-2323. [CrossRef]

8. Muraleedharan, K.; Nandy, T.K.; Banerjee, D.; Lele, S. Transformations in a Ti-24Al- 15Nb alloy: Part II. a composition invariant $\beta \mathrm{o} \rightarrow \mathrm{O}$ transformation. Metall. Mater. Trans. A 1992, 23, 417-431. [CrossRef]

9. Banerjee, D. The intermetallic Ti2AlNb. Prog. Mater. Sci. 1997, 42, 135-158. [CrossRef]

10. Cai, Q.; Li, M.C.; Zhang, Y.R.; Liu, Y.C.; Li, H.J. Precipitation behavior of Widmansttten O phase associated with interface in aged Ti2AlNb-based alloys. Mater. Charact. 2018, 145, 413-422. [CrossRef]

11. Germann, L.; Banerjee, D.; Guédou, J.Y.; Strudel, J.L. Effect of composition on the mechanical properties of newly developed Ti2AlNb-based titanium aluminide. Intermetallics 2005, 13, 920-924. [CrossRef]

12. Xue, C.; Zeng, W.D.; Wang, W.; Liang, X.B.; Zhang, J.W. The enhanced tensile property by introducing bimodal size distribution of lamellar $\mathrm{O}$ for O+B2 Ti2AlNb based alloy. Mater. Sci. Eng. A 2013, 587, 54-60. [CrossRef]

13. Wang, W.; Zeng, W.D.; Xue, C.; Liang, X.B.; Zhang, J.W. Designed bimodal size lamellar O microstructures in Ti2AlNb based alloy: Microstructural evolution, tensile and creep properties. Mater. Sci. Eng. A 2014, 618, 288-294. [CrossRef]

14. Wang, W.; Zeng, W.D.; Xue, C.; Liang, X.B.; Zhang, J.W. Microstructure control and mechanical properties from isothermal forging and heat treatment of Ti-22Al-25Nb (at.\%) orthorhombic alloy. Intermetallics 2015, 56, 79-86. [CrossRef]

15. He, Y.-S.; Hu, R.; Luo, W.-Z.; He, T.; Lai, Y.-J.; Du, Y.-J.; Liu, X.-H. Microstructure and mechanical properties of a new Ti2AlNb-based alloy after aging treatment. Rare Met. 2018, 37, 942-951. [CrossRef]

16. He, L.J.; Su, H.H.; Xu, J.H.; Zhang, L. Study on dynamic chip formation mechanisms of Ti2AlNb intermetallic alloy. Int. J. Adv. Manuf. Technol. 2017, 92, 4415-4428. [CrossRef]

17. Wang, W.; Zeng, W.D.; Li, D.; Zhu, B.; Zheng, Y.P.; Liang, X.B. Microstructural evolution and tensile behavior of Ti2AlNb alloys based $\alpha 2$-phase decomposition. Mater. Sci. Eng. A 2016, 662, 120-128. [CrossRef]

18. Kumpfert, J.; Leyens, C. Orthorhombic Titanium Aluminides: Intermetallics with Improved Damage Tolerance; Wiley-VCH Verlag GmbH \& Co. KGaA: Weinheim, Germany, 2003; pp. 59-88.

19. He, Y.S.; Hu, R.; Luo, W.Z.; He, T.; Lai, Y.J.; Du, Y.J.; Liu, X.H. Microstructural evolution and creep deformation behavior of novel Ti-22Al-25Nb-1Mo-1V-1Zr-0.2Si (at.\%) orthorhombic alloy. Trans. Nonferrous Met. Soc. China 2019, 29, 313-321. [CrossRef]

20. Gustafson, A.; Hättestrand, M. Coarsening of precipitates in an advanced creep resistant $9 \%$ chromium steel-quantitative microscopy and simulations. Mater. Sci. Eng. A 2002, 333, 279-286. [CrossRef]

21. Zhang, H.Y.; Li, C.; Ma, Z.Q.; Yu, L.M.; Liu, Y.C. Effect of dual aging treatments on phase transformation and microstructure in a pre-deformed Ti2AlNb-based alloy containing $\mathrm{O}+\beta / \mathrm{B} 2$ structures. Vacuum 2019, 164, 175-180. [CrossRef]

22. Tang, B.; Kou, H.C.; Zhang, W.; Gao, P.Y.; Li, J.S. Study on the formation mechanism of $\alpha$ lamellae in a near $\beta$ titanium alloy. Prog. Nat. Sci. 2016, 26, 385-390. [CrossRef]

23. Da Costa Teixeira, J.; Appolaire, B.; Aeby-Gautier, E.; Denis, S.; Bruneseaux, F. Modeling of the effect of the $\beta$ phase deformation on the $\alpha$ phase precipitation in near- $\beta$ titanium alloys. Acta Mater. 2006, 54, 4261-4271. [CrossRef] 
24. Appolaire, B.; Héricher, L.; Aeby-Gautier, E. Modelling of phase transformation kinetics in Ti alloys-Isothermal treatments. Acta Mater. 2005, 53, 3001-3011. [CrossRef]

25. Muraleedharan, K.; Gogia, A.K.; Nandy, T.K.; Lele, D.B. Transformations in a Ti-24AI-15Nb alloy: Part I. Phase equilibria and microstructure. Metall. Mater. Trans. A 1992, 23, 401-415. [CrossRef]

26. Zhao, Z.B.; Wang, Q.J.; Hu, Q.M.; Liu, J.R.; Yu, B.B.; Yang, R. Effect of $\beta$ (110) texture intensity on $\alpha$-variant selection and microstructure morphology during $\beta \rightarrow \alpha$ phase transformation in near $\alpha$ titanium alloy. Acta Mater. 2017, 126, 372-382. [CrossRef]

27. Wang, S.C.; Aindow, M.; Starink, M.J. Effect of self-accommodation on $\alpha / \alpha$ boundary populations in pure titanium. Acta Mater. 2003, 51, 2485-2503. [CrossRef]

28. Van Bohemen, S.M.C.; Kamp, A.; Petrov, R.H.; Kestens, L.A.I.; Sietsma, J. Nucleation and variant selection of secondary $\alpha$ plates in a $\beta$ Ti alloy. Acta Mater. 2008, 56, 5907-5914. [CrossRef]

29. Popille, F.; Douin, J. The dislocation microstructure in orthorhombic O Ti2AlNb deformed between room temperature and $800^{\circ} \mathrm{C}$. Philos. Mag. A 1996, 73, 1401-1418. [CrossRef]

30. Boehlert, C.J. Part III. The tensile behavior of Ti-Al-Nb O+Bcc orthorhombic alloys. Metall. Mater. Trans. A 2001, 32, 1977-1988. [CrossRef]

31. Xue, C.; Zeng, W.D.; Wang, W.; Liang, X.B.; Zhang, J.W. Coarsening behavior of lamellar orthorhombic phase and its effect on tensile properties for the Ti-22Al-25Nb alloy. Mater. Sci. Eng. A 2014, 611, 320-325. [CrossRef]

32. Cowen, C.J.; Boehlert, C.J. Microstructure, creep, and tensile behavior of a Ti-21Al-29Nb(at.\%) orthorhombic+B2 alloy. Intermetallics 2006, 14, 412-422. [CrossRef]

Publisher's Note: MDPI stays neutral with regard to jurisdictional claims in published maps and institutional affiliations. 